International Journal of Engineering \& Technology, $9(1)(2020) 218-222$
International Journal of Engineering \& Technology
SPC
Website: www.sciencepubco.com/index.php/IJET
Research paper

\title{
Influence of hydrated lime and bitumen on different lateritic soil samples: case study of Sheda-Abuja, Nigeria
}

\author{
Igibah Ehizemhen C ${ }^{1}$, Agashua Lucia O ${ }^{1}$, Sadiq Abubakar A ${ }^{1}$ \\ ${ }^{1}$ Civil Engineering Department, University of Abuja, F.C.T, Nigeria \\ *Corresponding author E-mail: igibahchrist1@gmail.com
}

\begin{abstract}
This research was performed so as to appraise strength and properties of lateritic soils enriched with hydrated lime and bitumen as construction materials. Soil samplings S1, S2, S3, S4, and S5 was collected from Dualization of Sheda - Abaji, Abuja, F.C.T, Ni-geria and augment with $0,3,6,9$, and $12 \%$ of hydrated lime and bitumen. Laboratory tests like Consistency (Atterberg limit), California Bearing Ratio (C.B.R), compaction and sieve scrutiny were done on the soil sampling. The study exposed that construc-tive effects were gotten via the addition of hydrated lime and bitumen in order to augment the strength of weak soils. All the 5 samplings have C.B.R values of $48.0 \%$ with hydrated lime as additives, whereas bitumen additive is $40.60 \%$. Introduction of addi-tives enriched the soil samplings from weak materials to an excellent base material with C.B.R values above $40 \%$. Hence, aug-mentation of lateritic soil samplings from the studied locality could be perform efficiently by using lime.
\end{abstract}

Keywords: Hydrated Lime; Bitumen; Strength; Lateritic Soils; Atterberg Limit.

\section{Introduction}

Lateritic soil is a layer of the soil which is gotten from rock weathering variability under intensely oxidation, leading situations as well as rich in iron oxide (Ali 2012; Amu et al. 2011). The features of a soil could be enriched thru several approaches, including stabilization. It has been proven that the characteristics of some lateritic soil in the tropical regions of sub-Saharan Africa might be enriched by several techniques of stabilization (Latifi et al. 2013; Amu et al. 2011). From the time when method of stabilization initiated, most soil that has been considered as unsuitable materials has found application in several engineering areas. Likewise, as the world inhabitants continue to increase, request for housing also does (Wright and Dixon 2013). The rise in inclination of accommodation create shortage for the builtup as well as peri-municipal regions in developing nations, which in turn inspired research into numerous high-tech solutions, which include improved diversities in the enhancement and usage of local soil materials (Nnochri 2018; Akinje 2015; Akinwumi 2014). Soil enhancement (stabilization) is the method of integrating additives with soil so as to enrich its strength, volume stability, absorptivity as well as durability (Joel and Edeh 2015; Ali 2012; Amu et al. 2008). The necessities of soil stabilization as cost-effective building materials cannot be overstressed. Lateritic soil with good attribute will have low surface cracks for insects to stay, lessen maintenance as well as renovation costs and, at large, prolong the life-span of construction works (Bagher et al. 2014; Amu et al. 2011; Rigassi 1995). Knowledge about the stabilizers constituent requirement for lateritic soil material is significant in order to discover the durability as well as strength of construction materials. The properties of hydrated lime, Portland cement and stabilized lateritic soils were summarized by (Wright and Dixon 2013; Bell 1993). Likewise, the basic rules for cement stabilization with recommendation of five (5) to ten percent (10\%) cement stabilization as guide, so as to attain saturated. It was publicized by Solanke (1998) that lateritic soil can be enriched by being careful during mixing composition and its process, as well as stabilizing. With this, the properties of the soil material concerning any application that is being designed for become vital. It was perceived that compacting soils via machine-driven press increases their strength (Sadeeg et al. 2015; Rigassi 1995). Also, perceived that the greater the density obtained, the better the strength attained. The aim of this paper was to assess the engineering properties and strength of lateritic soils stabilized with hydrated lime as well as bitumen as construction material.

\section{Materials and methods}

\subsection{Preparation of materials}

The lateritic soil sampling utilized for this research work was obtained from borrow pit within the Dualization of Sheda-Abaji road project in Abuja, Nigeria. Hydrated lime and bitumen used were obtained from Deidei market and RCC construction site at Kwali- Abuja respectively. Potable water was also used during mixture of materials to produce soil stabilizer.

\subsection{Methods}




\subsubsection{Geotechnical scrutiny}

Tests like sieve scrutiny (particle size distribution) and consistency (Plasticity Index) tests were carried out on the lateritic soil sampling so as to categorize the soil. The technique utilized for these tests are in agreement with $(B S 1377,1990)$ which endorse terminologies as well as the Unified Soil Classification System (USCS) to define and categorize lateritic soils for engineering reasons.

\subsubsection{Compaction}

Compaction test were performed on the raw soils samplings obtained from Sheda-Abaji Highway after which 3, 6, 9, and 12 percent of hydrated lime and bitumen, were introduced as soil admixtures. The soil samplings were broken up, 500grams of each sampling was measured with approximately four percent (4\%) of water added, after thorough mixture the sampling was divided into three equal portions and compacted in three layers inside B.S mould with 25 uniformly blows via $5.5 \mathrm{Kg}$ rammer at height of 12 inches. The compacted sampling as well as mould was weighed, and rep sampling for dry density and moisture content determination was taken. The same approach was used for the entire admixture at different percentage. Dry density versus water content was plotted to form a curve, while the maximum dry density is referred to as Zero air voids. Likewise, the Optimum moisture content (OMC) determined is utilized during construction work for regulating the quantity of water to be added to earthworks.

\subsubsection{California bearing ratio (C.B.R)}

For C.B.R test, roughly six kilograms of soil samplings that pass through number four sieve was mixed with the OMC gotten from compaction test. This entails compaction of soil thrice with fifteen (15) blows and 2.5 kilograms rammer. Both compacted soil and the mould were positioned under C.B.R machine with application of penetrations at 25, 50, 15, 100, 125 and 750 inches, which was done for top and bottom layer. The C.B.R test is principally a penetration test with the function of assessing the soil resistance to penetration erstwhile to reading so as to evaluation shearing value.

$$
\text { C.B.R } \%=(\text { Test load }- \text { Standard load }) \times 100
$$

\section{Results and discussion}

Laboratory test were carried out on the three samplings obtained for the purpose of sorting, categorization and determination of the engineering physiognomies of the material used as exhibited in Table 1 . The samplings were treated with $3 \%, 6 \%, 9 \%$ and $12 \%$ of hydrated lime and bitumen in the research laboratory for properties assessment.

Table 1: Engineering Physiognomies of the Selected Lateritic Soil

\begin{tabular}{|c|c|c|c|c|c|c|}
\hline \multirow{2}{*}{ PROPERTIES } & \multirow{2}{*}{ Unit } & \multicolumn{5}{|c|}{ SOIL SAMPLINGS } \\
\hline & & S1 & S2 & S3 & S4 & S5 \\
\hline Grain Size Dispersal & $\%$ & & & & & \\
\hline Coarse & $\%$ & 90.85 & 91.45 & 91.55 & 91.65 & 91.68 \\
\hline Fine & $\%$ & 09.15 & 08.55 & 08.45 & 08.35 & 08.32 \\
\hline Bulk density & $\mathrm{KN} / \mathrm{m}^{3}$ & $14.64-29.76$ & $14.53-29.26$ & $14.44-28.78$ & $14.42-27.76$ & $14.39-27.74$ \\
\hline Consistency Limit & $\%$ & & & & & \\
\hline LL (Liquid Limit) & & 43.80 & 43.50 & 42.50 & 42.00 & 41.97 \\
\hline Pl (Plastic Limit) & & 19.09 & 25.65 & 26.33 & 22.09 & 22.59 \\
\hline PI (Plasticity Index) & & 24.41 & 17.85 & 16.17 & 19.91 & 19.38 \\
\hline MDD & $\mathrm{KN} / \mathrm{m}^{3}$ & 18.85 & 18.62 & 18.54 & 18.68 & 18.64 \\
\hline $\mathrm{OMC}$ & $\%$ & 9.95 & 9.90 & 9.85 & 9.82 & 9.88 \\
\hline C.B.R & $\%$ & 9.88 & 9.78 & 9.72 & 9.72 & 9.78 \\
\hline Soil Classification & & A-2-7 & A-2-7 & A-2-7 & A-2-7 & A-2-7 \\
\hline Soil Type & Clayed $\mathrm{c}$ & lty gravel sand & & & & \\
\hline
\end{tabular}

\subsection{Sieve scrutiny}

The outcomes of the particle size scrutiny are graphically displayed in Fig. 1 for the three samplings obtained from Sheda-Abaji highway, Abuja. The result indicates that sampling S1 greater in fine as well as bulk density than other samples, whereas sampling S5 higher in coarse aggregate than other samples. 


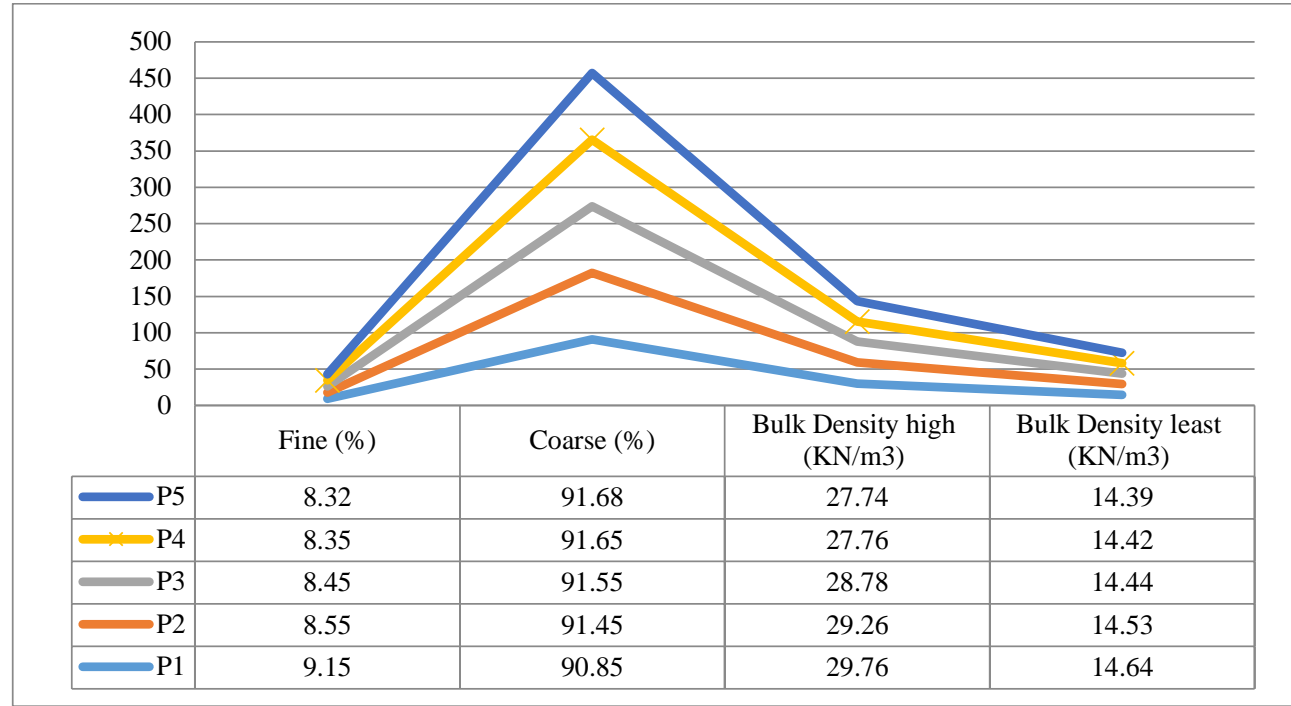

Fig. 1: Chart of Sieve Analysis.

Table 2: Atterberg Limit Test Control, Hydrated Lime and Bitumen Treated, Sampling At 3 and $12 \%$

\begin{tabular}{|c|c|c|c|c|}
\hline Samples & & Liquid Limit (LL) \% & Plastic Limit (PL) \% & Plasticity index (PI) \% \\
\hline \multirow{6}{*}{ Control $(0 \%)$} & $\mathrm{S} 1$ & 43.80 & 19.09 & 24.41 \\
\hline & $\mathrm{S} 2$ & 43.50 & 25.65 & 17.85 \\
\hline & S3 & 42.50 & 26.33 & 16.17 \\
\hline & S4 & 42.00 & 22.09 & 19.91 \\
\hline & S5 & 41.97 & 22.59 & 19.38 \\
\hline & Average & 42.75 & 23.15 & 19.54 \\
\hline \multirow{6}{*}{ Bitumen treated (3\%) } & $\mathrm{S} 1$ & 42.75 & 21.60 & 21.15 \\
\hline & $\mathrm{S} 2$ & 42.54 & 21.45 & 21.09 \\
\hline & S3 & 42.60 & 21.50 & 21.10 \\
\hline & S4 & 42.18 & 21.05 & 21.13 \\
\hline & S5 & 42.10 & 21.00 & 21.10 \\
\hline & Average & 42.43 & 21.32 & 21.11 \\
\hline \multirow{6}{*}{ Lime treated $(3 \%)$} & S1 & 46.80 & 26.49 & 20.31 \\
\hline & $\mathrm{S} 2$ & 45.80 & 26.50 & 19.30 \\
\hline & S3 & 46.45 & 26.75 & 19.70 \\
\hline & S4 & 46.78 & 26.76 & 20.02 \\
\hline & S5 & 45.90 & 26.80 & 19.10 \\
\hline & Average & 46.35 & 26.66 & 19.69 \\
\hline \multirow{6}{*}{ Bitumen treated (12\%) } & $\mathrm{S} 1$ & 36.48 & 30.50 & 5.98 \\
\hline & $\mathrm{S} 2$ & 35.95 & 28.50 & 7.45 \\
\hline & S3 & 36.34 & 29.20 & 7.14 \\
\hline & S4 & 35.92 & 28.45 & 7.47 \\
\hline & S5 & 36.52 & 29.02 & 7.50 \\
\hline & Average & 36.24 & 29.13 & 7.11 \\
\hline \multirow{6}{*}{ Lime treated $(12 \%)$} & P1 & 38.62 & 32.85 & 5.77 \\
\hline & $\mathrm{P} 2$ & 37.94 & 31.19 & 6.75 \\
\hline & P3 & 36.90 & 30.50 & 6.40 \\
\hline & $\mathrm{P} 4$ & 37.46 & 31.29 & 6.17 \\
\hline & P5 & 37.84 & 31.34 & 6.50 \\
\hline & Average & 37.75 & 31.43 & 6.32 \\
\hline
\end{tabular}

\subsection{Atterberg Limits}

The results of Atterberg limits scrutiny are presented in Table 2, also graphically displayed in Fig. 2 for the three samplings obtained from Sheda-Abaji highway, Abuja. The outcome discloses that the hydrated lime additive mean values at $3 \%$ Liquid limit as well as plastic limit values are above bitumen additive. Similarly Lime additive at $12 \%$ Liquid limit as well as plastic limit values are beyond bitumen additive. 


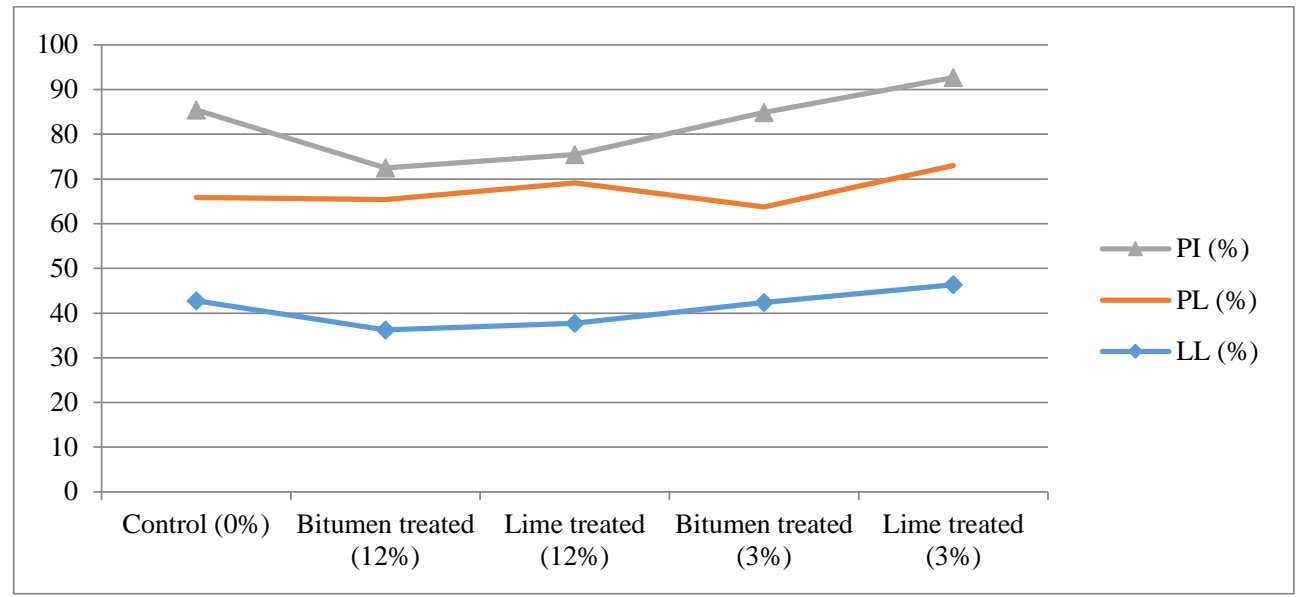

Fig. 2: Chart of Consistency (Atterberg) Limit Test.

Compaction and California bearing ratio (C.B.R) Test

The results of compaction test are demonstrated in Table 3, also graphically displayed in Fig. 3 for the three samplings obtained from Sheda-Abaji highway, Abuja. The three samplings indicate low dry densities which will cause low strength of the samplings if used as construction materials in its raw state. The average hydraulic lime additive at 3\% M.D.D value is above bitumen additive, whereas bitumen additive at $12 \%$ Maximum Dry density value is beyond hydraulic lime additive, but hydrated lime additive at $12 \%$ average Optimum dry density values larger than bitumen additive.

For C.B.R, the three samplings classified as poor sub-base materials with low dry density and strength based on AASHTO 2007. The average hydrated lime additive at 3 and $12 \%$ CBR is above bitumen additive.

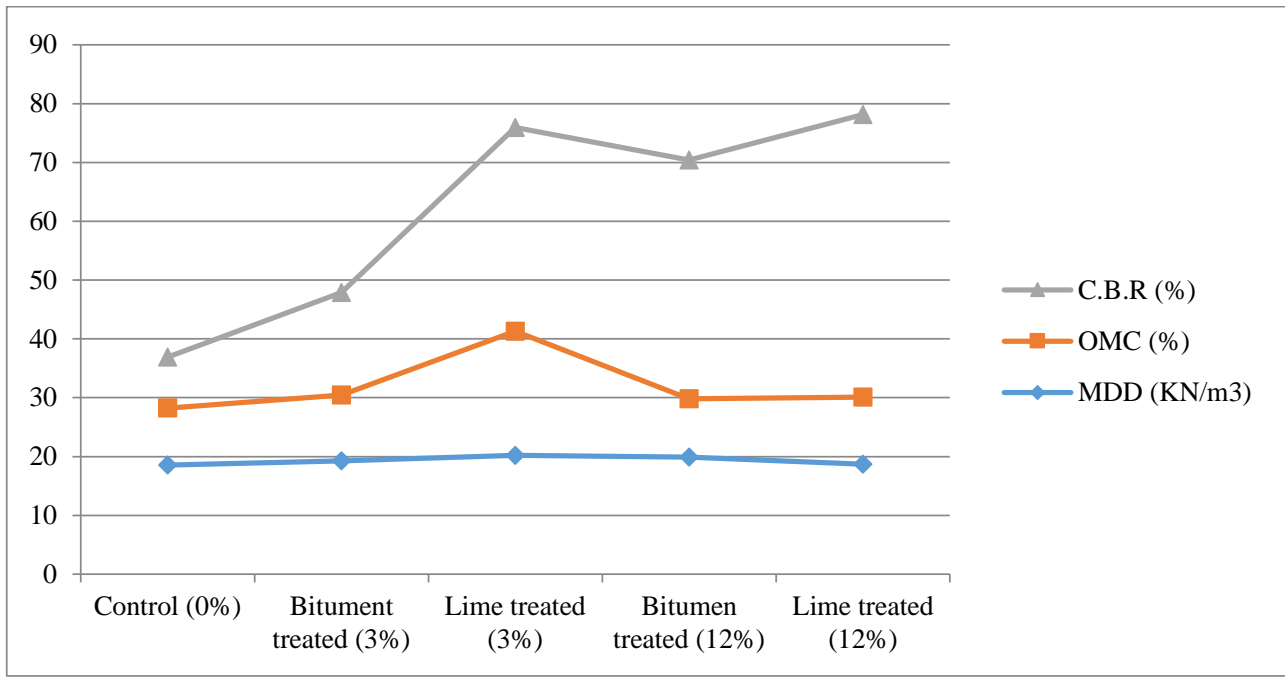

Fig. 3: Chart of Compaction and C.B.R Tests.

Table 3: Compaction and C.B.R Test Control, Hydrated Lime and Bitumen Treated, at 3 and 12\%

\begin{tabular}{|c|c|c|c|c|}
\hline Samples & & Maximum dry density (MDD) $\mathrm{KN} / \mathrm{m} 3$ & Optimum moisture content (OMC) \% & C.B.R $(\%)$ \\
\hline \multirow{5}{*}{ Control (0\%) } & S1 & & 09.90 & 9.98 \\
\hline & S2 & 18.6518 .62 & 09.85 & 9.88 \\
\hline & S3 & $\begin{array}{l}18.50 \\
18.52\end{array}$ & 09.45 & 8.36 \\
\hline & S4 & & 09.65 & 7.89 \\
\hline & S5 & 18.42 & 09.55 & 7.27 \\
\hline \multirow{8}{*}{ Bitumen treated (3\%) } & Average & 18.54 & 9.68 & 8.68 \\
\hline & S1 & 19.94 & 11.35 & 18.00 \\
\hline & S2 & 19.85 & 11.28 & 17.50 \\
\hline & S3 & 18.94 & 11.20 & 17.50 \\
\hline & S4 & 18.84 & 11.15 & 17.00 \\
\hline & S5 & 18.65 & 11.12 & 17.00 \\
\hline & Average & 19.24 & 11.22 & 17.40 \\
\hline & S1 & 20.40 & 21.60 & 35.00 \\
\hline \multirow{5}{*}{ Lime treated (3\%) } & S2 & 19.80 & 20.40 & 34.05 \\
\hline & S3 & 20.20 & 20.80 & 34.50 \\
\hline & S4 & 20.35 & 21.30 & 34.80 \\
\hline & S5 & 20.24 & 21.40 & 34.95 \\
\hline & Average & 20.20 & 21.10 & 34.66 \\
\hline \multirow{6}{*}{$\begin{array}{l}\text { Bitumen } \\
\text { treated (12\%) }\end{array}$} & $\mathrm{S} 1$ & 20.02 & 10.05 & 41.00 \\
\hline & S2 & 19.96 & 10.02 & 40.50 \\
\hline & S3 & 19.84 & 10.00 & 40.50 \\
\hline & S4 & 19.70 & 9.92 & 40.50 \\
\hline & S5 & 19.72 & 9.74 & 40.50 \\
\hline & Average & 19.88 & 9.95 & 40.60 \\
\hline
\end{tabular}




\begin{tabular}{lllll}
\hline & P1 & 19.0018 .30 & 12.25 & 48.00 \\
Lime treated $(12 \%)$ & P2 & 19.00 & 12.24 & 48.00 \\
& P3 & 18.50 & 12.20 & 12.22 \\
\\
& P5 & 18.80 & 12.23 & 48.00 \\
& Average & 18.72 & 12.23 & 48.00 \\
48.00 & \\
\hline
\end{tabular}

\section{Conclusion}

The research on lateritic soil samplings from a construction site situated at Sheda - Abaji, Abuja, revealed that constructive impacts are achieved by the addition of hydrated lime and bitumen, so as to enhance the strength of weak soil. All the lateritic soil sampling S1 to S5 belong to A-2-7 which is clayed or silty gravel sand. Sampling Atterberg Limits results ranges from 35.92 to $46.80 \%$ for Liquid Limit whereas, plasticity index is from 5.77 to $24.41 \%$. Atterberg limit result at $3 \%$ as well as $12 \%$ hydrated lime additive LL higher, while for PI bitumen additive is higher. For Compaction, MDD and OMC at 3\% hydrated lime additive is above bitumen additive, whereas at $12 \%$, hydrated lime MDD values is higher but bitumen additive higher in OMC. As percentage of hydrated lime additive increases, both LL and $\mathrm{Pl}$ also decrease, this shows that slight percentage of hydrated lime and moderate percent of bitumen will augment the soil strength. Lesser percent of hydrated lime and bigger percent of bitumen additive gave maximum values of MDD as well as OMC correspondingly. With slight quantities of hydrated lime additive and considerable amount of bitumen, soil enhancement will be great, and this is in agreement with (Amu and Babajide 2011; Amu et al. 2011). Thus, enhancement of lateritic soil samplings from the studied localities can be perform effectively via hydrated lime additives

\section{References}

[1] Akinje, I. (2015). Comparison Characterization of A-6(10) laterite soil stabilized with powermax cement and hydrated Lime separately. International journal of Engineering and technology, (7): 392 - 401.

[2] Akinwumi, I. (2014). Plasticity, Strength and Permeability of Reclaimed Asphalt and Lateritic Soil Blends. International Journal of Scientific and Enginnering Reseach,, 5 (6): 631-636.

[3] Ali, F. (2012). Stabilization of Residual Soils Using Liquid Chemical. The electronic journal of Geotechnical Engineering Science and Technology, $1(2): 102-110$.

[4] Amu O. O, Bamisaye O. F. and Komolafe I. A. (2011) The Suitability and Lime Stabilization Requirement of some lateritic soil samples as pavement. International Journal of Pure and Applied Sciences Technology, 1(2): 29 - 46.

[5] Amu, O. O. \& Babajide, S.S. (2011). Effects of Bamboo Leaf Ash on Lime Stabilized Lateritic Soil for Highway Construction. Research Journal of Applied Sciences, Engineering and Technology 3 (4): Pp 278-283, 2011.

[6] Amu, O.O., Adewumi, I.K., Mustapha, R.A. and Ola, O.O. (2008). "Analysis of California bearing ratio values of lime and wood ash stabilized lateritic soil". Ife Journal of Science, 10(1): 121-126. African Journals Online (AJOL).

[7] Bagheri Y, F. Ahmad, and M. A. M. Ismail (2014). Strength and mechanical behavior of soil-cement-lime-rice husk ash (soil- CLR) mixture, Materials and Structures, vol. 47 , no. 1-2, pp. 55- 66. https://doi.org/10.1617/s11527-013-0044-2.

[8] Joel, M. \& Edeh, J. E. (2015). Comparative Analysis of Cement and Lime Modification of Ikpayongo Laterite for Effective and Economic Stabilization. Journal of Emerging Trends in Engineering and Applied Sciences (JETEAS) 6 (1): 49-56. https://doi.org/10.4314/gjpas.v20i1.8.

[9] Nnochiri E. S. (2018). Effects of corn cob ash on lime stabilized lateritic soil. Journal of civil engineering Special Issue. https://doi.org/10.1515/sspjce-2018-0007.

[10] Sadeeg, J.A., Ochepo, J., Salahudeen, A.B and Tijani (2015) "Effect of Bagassse Ash on Lime Stabilized Lateritic soil "Jordan Journal of Civil Engineering, Vol 9, No.2.

[11] Latifi, N, Marto A and A Eisazadeh . (2013). Structural characteristics of Lateritic soil treated bu SH 85 and TX - 85/ Nontraditional stabilizers. The Electrronic Journal of Geotechnical Engineering, 1(3): 1707 - 1718.

[12] Wright P.H and Dixon K.K. Highway Engineering. (2013). $7^{\text {th }}$ ed., New York: Wiley and sons.

[13] Bell F.G. (1993). Engineering Treatment of Soil: Soil Stabilization (London: E and FN SPON.

[14] Solanke O. (1998). An application of Borassus Flabillater to reinforce the superficial leaf of mud-wall, doctoral diss., Ahmadu Bello University, Zaria.

[15] Rigassi V. (1995). Compressed earth blocks, Vol. 1. manual of production (Germany, Friedrich Vieweg \& Sohn.

[16] British Standard, Methods of test for soils for civil engineering purposes (London, British Standard Institution, BS1377, 1990). 